\title{
Influence of the Friction Time on the Shape and Microstructure of the Mixing Zone of the Friction Welded Joint
}

\author{
Nada Ratković ${ }^{1}$, Vukić Lazić ${ }^{1}$, Dušan Arsić ${ }^{1}$, Ružica R. Nikolić1,2, Jozef Meško ${ }^{3}$, Rastislav Nigrovič ${ }^{3}$ \\ ${ }^{1}$ Faculty of Engineering, University of Kragujevac, Sestre Janjić 6, 34000 Kragujevac, Serbia. E-mail: nrat- \\ kovic@kg.ac.rs, vlazic@kg.ac.rs, dusan.arsic@fink.rs \\ ${ }^{2}$ Research Center, University of Zilina, Univerzitna 1/2815, 01026 Zilina, Slovakia. E-mail: ruzicarnikolic@yahoo.com \\ ${ }^{3}$ Faculty of Mechanical Engineering, University of Zilina, Univerzitna 1/2815, 01026 Zilina, Slovakia. E-mail: \\ Jozef.Mesko@fstroj.uniza.sk, Rastislav.Nigrovic@fstroj.uniza.sk
}

\begin{abstract}
An analysis of the friction time influence on creation and structure of the mixing zone during the friction welding process of the two dissimilar steels is presented in this paper. The changes were monitored on the two welded samples, made of the highly-alloyed steel HS 6-5-2-5 and the high carbon C60 steel. The objective of this work was to show how the mixing zone is created and to point to its influence on the quality of the whole welded joint, since it is characterized by the inhomogeneity of the microstructure and the chemical composition. Those problems arise due to the thermal and deformation conditions, so during the experiment the welding pressure (70-90 MPa) and the welding time (3-18 s) variations were monitored. Experimental results have shown that the shape and the structure of the friction zone are strongly dependent on the friction time and that by its variation one can obtain the desired structure and thus the quality of the friction welded joint. Based on obtained results the minimum value for the friction time is recommended.
\end{abstract}

Keywords: Friction time, mixing zone, dissimilar steels, microstructure, welded joint quality

\section{Acknowledgment}

This research was partially financially supported by the Ministry of Education, Science and Technological Development of Republic of Serbia through Grants TR35024 and ON174004 and Slovak state budget by the project "Research Centre of the University of Žilina" - ITMS 26220220183.

\section{References}

[1] RATKOVIĆ, N., NIKOLIĆ, R., SAMARDŽIĆ, I. (2014). Structural, chemical and deformation changes in friction welded joint of dissimilar steels. Metalurgija-Metallurgy, Vol. 53, No. 4, pp. 513-516. Croatia.

[2] RATKOVIĆ, N., SEDMAK, A., JOVANOVIĆ, M., LAZIĆ, V., NIKOLIĆ, R.; KRSTIĆ, B. (2009). Physical and metallurgical changes during the friction welding of the high-speed steel and the tempering steel. Tehnički vjesnik - Technical Gazette, Vol. 16, No. 1, pp. 27-31. Croatia.

[3] KONAR, R., PATEK, M. (2016). Prediction of Hardness and Residual Stresses of Dissimilar Weld Joint. Manufacturing Technology, Vol. 16, No. 2, (2016), pp. 365-371. Czech Republic.

[4] RATKOVIĆ, N., ARSIĆ, D., LAZIĆ, V., NIKOLIĆ, R., HADZIMA, B. (2016). The contact and compacting pressures influences on the plastic deformation parameters of the friction welded joint. Materials Engineering Materialove inzinierstvo, Vol. 23, No. 2, pp. 51-57. Slovakia.

[5] SAHIN, M. (2005). Joining with Friction Welding of high - speed steel and medium - carbon steel. Journal of Materials Processing Technology, Vol. 11, pp 469-475. The Netherlands.

[6] SAVIĆ B., MARKOVIĆ S., ĆIRIĆ R. (2008). Physical model of the friction welded joint of different types of steel. FME Transactions, Vol. 36, No. 2, pp. 93-97. Serbia.

[7] RATKOVIĆ, N. (2009). Modeling of the machine parts of various forms of the welding process. PhD thesis, Faculty of Mechanical Engineering, Kragujevac, 2009. Serbia.

[8] HANDA, A., CHAWLA, V. (2013). Mechanical characterization of friction welded dissimilar steels at $1000 \mathrm{rpm}$. Materials Engineering - Materialove inzinierstvo, Vol. 20, No. 3, pp. 102-111. Slovakia.

[9] HANDA, A., CHAWLA, V. (2014). Influence of process parameters on torsional strength, impact toughness and hardness of dissimilar AISI 304 and AISI 1021 friction welded steels. Materials Engineering - Materialove inzinierstvo, Vol. 21, No. 3, pp. 94-103. Slovakia.

[10] KUMAR, R., CHATTOPADHYAYA, S., HLOCH, S., KROLCZYK, G., LEGUTKO, S. (2016). Wear characteristics and defects analysis of friction stir welded joint of aluminum alloy 6061-T6. Eksploatacja i Niezawodnosc - Maintenance and Reliability, Vol. 18, No. 1, pp. 128-135. Poland. 
[11] RATKOVIĆ, N., SEDMAK A., JOVANOVIĆ, M., LAZIĆ, V., NIKOLIĆ, R., KRSTIĆ, B. (2009). Quality analysis of Al-Cu joint realized by friction welding. Tehnički vjesnik - Technical Gazette, Vol. 16, No. 3, pp. 3-7. Croatia.

[12] PRISCO, U., SCHERILLO, F. (2016). Tensile Properties of AA6156-T4 Friction Stir Welded Joints in As-Welded and Post-Weld Aged Condition. Manufacturing Technology, Vol. 16, No. 4, pp. 786-792. Czech Republic.

[13] VELJIĆ, D., SEDMAK, A., RAKIN, M., RADOVIĆ, N., POPOVIĆ, N., DASCAU, H., BAJIĆ, N. (2015). Advantages of friction stir welding over welding with respect to health and environmental protection and work safety. Structural Integrity and Life, Vol. 15, No. 2, pp. 111-116. Serbia.

[14] LIPIŃSKI, T. (2015). Influence of Surface Refinement on Microstructure of Al-Si Cast Alloys Processed by Welding Method. Manufacturing Technology, Vol. 15 No. 4, pp. 576-581. Czech Republic.

[15] MEŠKO, J., ZRAK, A., MULCZYK, K., TOFIL, S. (2014). Microstructure Analysis of Welded Joints after Laser Welding. Manufacturing Technology, Vol. 14, No. 3, pp. 355-359. Czech Republic.

[16] RATKOVIĆ, N., ARSIĆ, D., LAZIĆ, V., NIKOLIĆ, R., HADZIMA, B. (2016). Micro-structure in the joint friction plane in friction welding of dissimilar steels. Procedia Engineering, Vol. 149, pp. 414-420. The Netherlands.

[17] ARSIĆ, D, LAZIĆ, V., MITROVIĆ, S., DŽUNIĆ, D., ALEKSANDROVIĆ, S., DJORDJEVIĆ, M., NEDELJKOVIĆ, B. (2016). Tribological behavior of four types of filler metals for hard facing under dry conditions. Industrial Lubrication and Tribology, Vol. 68, in press. United Kingdom.

[18] MA, H, QIN, G, GENG, P, LI, F, FU, B, MENG, X., (2015). Microstructure characterization and properties of carbon steel to stainless steel dissimilar metal joint made by friction welding. Materials and Design, Vol. 86, pp. 587-597. The Netherlands. 